\title{
International Concept of an Assessment of Internal Control Efficiency in the Conduct of an Audit
}

\author{
Albina Serafimovna Mukhina ${ }^{1}$ \\ ${ }^{1}$ National research university "Higher School of Economics", Russian Federation \\ Correspondence: Albina Serafimovna Mukhina, Myasnitskaya Street, 20, Moscow, 101000, Russian Federation.
}

Received: November 17, 2014

Accepted: December 17, 2014 Online Published: March 20, 2015

doi:10.5539/ass.v11n8p58

URL: http://dx.doi.org/10.5539/ass.v11n8p58

\begin{abstract}
Internal control in the conduct of an audit creates real prerequisites for successful business development and growth of competitiveness of the enterprise. The main advantages of the availability of internal control system in the organization consist in the fact that in internal control may improve the quality of accounting of the company; internal control system has a positive effect on the further development of business. Another advantage of the presence of the internal control system is to improve the quality of work of the branches and structural divisions of the company in connection with the supervision of their activities. Internal control system the company is able to identify the hidden reserves on the use of material and labor resources, and stimulate the development of measures for reduction of production cost. In the article the notion and the basic elements of the internal control system during the conduct of an audit. Reviewed international framework for internal control in the conduct of an audit, which are used for the development of domestic procedures of internal control. The comparison and analysis of the concepts of internal control on the proposed criteria: definition; target group; orientation; principles; goals and objectives; composition; performance evaluation.
\end{abstract}

Keywords: internal control, the internal control system, internal control concepts, standards, efficiency

\section{Introduction}

Internal control as one of the functions of management is a system of ongoing monitoring and verification of the functioning of the organization in order to assess the reasonableness and effectiveness of managerial decisions, to identify abnormalities and adverse situations, timely informing management to make management decisions on elimination, reduction, risk management activities (Armour, 2000).

The internal control system should include: control environment, the species composition of the internal control, the description of subjects and objects of the internal control (Figure 1).

Key integrated element of the internal control system is the control environment, the role of which is to create conditions for effective interaction of the elements of the internal control system (Burtsev, 2000). Its status depends directly from the policy of the higher management of the company (Chenhall, 2003).

At the present stage in the development of effective internal control system at the international level has developed some concepts:

COSO "Internal control: an integrated approach" (the concept was developed by the Committee of Sponsoring Organizations of the Treadway Commission's Internal control-Integrated Framework) (Committee of Sponsoring Organizations of the Treadway Committee, 1992), SAC "Control and audit systems" (developed by the Institute of Internal Auditors Research Foundation's Systems Auditability and Control) (Mair, 2002), COBIT "Control objectives when using information technologies" (the concept was developed by ISACA, the Information Systems Audit and Control Foundation's Control Objectives for Information and related Technology) (IT Governance institute, http://www.isaca.org), SAS 55 и SAS 78 (standards on consideration of the internal control structure in an audit of financial statements, approved by the American Institute of Certified Public Accountants' Consideration of the Internal Control Structure in a Financial Statement Audit) (American Institute of Certified Public Accountants. Statement on Auditing Standards No. 53 and No. 78), Article 404 of Sarbanes-Oxley Act (Sarbanes-Oxley Act of 2002, https://www.sec.gov/about/laws/soa2002.pdf). 
Elements of the internal control system

Control environment:

1) Information support

2) Analytical support

3) Technical support

4) Staffing

5) Strategy and development policy of the organization

6) Organizational management structure

7) Forms and methods of control

8) The distribution of control functions, powers and responsibilities
Types of internal control
The subjects of internal control:

1) The representative bodies of the owners organization (audit Commission)

2) The top management

3) Special bodies performing control functions (internal control service and other)

4) Special commissions established on a temporary basis (for inventory purposes, etc.)

5) The managers and specialists of organizations

The objects of the internal control:

1) Financial and economic activities of the organization

2) The activity of structural subdivisions

3) Certain types of financial-economic activity, services, operations, transactions

4) Financial, informational and other threads

5) The performance of individual managers and specialists of organizations

Figure 1. Elements of the internal control system

\section{International Concept of Internal Control}

The concept of the COSO (1992) "Internal control: an integrated approach" defines the main provisions of the building of internal control, based on the monitoring of economic risks (Committee of Sponsoring Organizations of the Treadway Committee, 1992). Currently these provisions are taken as a basis in the majority of developments in this area and have become widely used. The essence of the risk-based approach is that the planning of works on internal audit is organized in predefined areas, which are subject to insignificant risk.

COSO concept defines internal control as a process, conducted by the Board of Directors, the company's management or other personnel, designed to provide reasonable assurance that the following objectives will be achieved and results of operations, drive for results; ensuring the reliability prepare financial statements, compliance with corporate standards, laws of the country (International Standards for the Professional Practice of Internal Auditing, 2012).

The system of internal control consists of five interrelated components: 1) control environment; 2) risk assessment; 3) actions for the implementation of the control; 4) information and communication; 5) monitoring.

The concept SAC (1991) "Control and audit systems" offers support to the auditors in the issues of control and audit in the conditions of information systems, provides detailed guidance concerning the study of the influence of the various components of information technologies on the internal control system (Mair, 2002).

SAC defines the internal control system as a set of business processes, functions, subsystems and users, aimed at achieving the goals and objectives of the company.

Duties of internal auditors include ensuring the adequacy of the internal control system, data reliability, efficient use of resources of the organization. Internal auditors can also prevent and detect fraud and to coordinate interaction with the external auditors.

The document COBIT (1996) is an approach, a system that provides executives special tool, which provides full control over the company's activities in the context of business processes. 
In the COBIT standard "Control objectives when using information technologies" formulated procedure and criteria of evaluation of internal control of the information system for management (its confidentiality, integrity, compliance with the criteria of efficiency, performance, security, consistency, reliability) (IT Governance institute, http://www.isaca.org).

Structure COBIT enables managers to compare with the best samples of own practice reliability and control, to ensure the existence of adequate level of reliability and control, and auditors-to justify judgment on internal control and advise on the reliability and control. The main motive for the creation of this structure was to develop a clear policy and disseminate good practice of internal control throughout the world. Full set of documents COBIT currently includes: 1) Executive Summary; 2) Framework; 3) Control Objectives; 4) Audit Guidelines.

In accordance with the standard COBIT "Control objectives when using information technologies", information about intangible assets must meet the following criteria (Colbert \& Bowen, 1996):

efficiency-date information on the status of the accounting and internal control intangible assets, warranty regular get the correct information;

performance-ensuring the availability of information about the accounting of intangible assets, due to the most productive use of resources;

confidentiality-protection of information about intangible assets from unauthorized its registration;

integrity, accuracy, reliability, completeness information about intangible assets in accordance with business requirements;

consistency-compliance with information about the objects intangible assets laws, rules, treaties.

The following stages of the project development COBIT include the development of a manual for self-assessment by management, and identification of new or updated purposes of control by merging with other established standards of global control. In addition, will be complemented papers on the organization of control and defined key performance indicators.

The document COBIT updated definition of control from the document COSO. The control appears as a set of norms and procedures established in the company to achieve the set level of confidence in the reliability of reporting, achieving the goals of the company, to prevent, detect and eliminate fraud and abuse.

Standards SAS 55 (1988) and SAS 78 (1995) (standards on consideration of the internal control structure in a financial statement audit) provide guidance to the external auditors regarding the study of the influence of internal control in planning and conducting audit of financial reporting institutions, which are adapted elements of internal control concept COSO.

The document SAS 78 replaces the definition of internal control of the document SAS 55 definition of the COSO report, but focuses on the main goals of internal control - ensuring the reliability of financial reporting. Thus, SAS 78 gives this definition internal control is a process aimed at achieving a set level of confidence and achieve the following objectives: the reliability of financial reporting; effectiveness of operations, result orientation; corporate standards, the laws of the country.

This definition shows that the main emphasis in the documents SAS 55 and SAS 78 aimed at the controls that are used to verify the reliability of financial reporting of the company.

The document SAS 78 replaces the three components of internal control of the document SAS 55 (control environment, the system of accounting, control procedures) five elements, similar COSO (the control environment, risk assessment, control, information and communication, and monitoring).

SAS 55 and SAS 78 establish the duties of the external auditor's understanding of the internal policies of the audited company and procedures, and thus each of the five elements of the system. The external auditors, as a rule, check the statement for a certain period, and therefore in their interest to get all the controls involved in this period. The external auditors report to the heads and control service of any deficiencies in the internal control system, which may affect the reliability of financial reporting. At its discretion, the external auditors may also spread in the organization of other issues related to control, for example, opportunities for improvement of the accounting system of accounts receivable.

The scandal at Enron and Arthur Andersen had a great influence on the activity of business entities in the US. In connection with these events in 2002 in the light went out of the Sarbanes-Oxley act (Sarbanes-Oxley Act of 2002), which became one of the most basic legislative acts of the United States of America on corporate 
governance and the fight against fraud.

The law is named by names offered his Senator Paul Sarbanes and representative Michael Oxley act. Currently this act also applies to non-U.S. companies, whose shares are traded on the stock market of the USA.

To ensure the reliability of financial reporting, the law encourages companies to pay special place audit, organize, if possible, audit committees, control services, which will be fully responsible for the conduct of internal and external audit of the company. The auditor shall immediately inform the audit Committee about all detected errors and omissions in the financial system, variants of correction and prevention. In the event of disputes or disagreements between managers and auditors the audit Committee acts as a link.

Article 404 of the Sarbanes-Oxley Act requires all companies more detailed decoding of the main items of the annual financial statements. Appoints the company's management is responsible for implementing the procedures of internal control, management accounting and budgeting. The rules also include assessment of the effectiveness of internal control procedures of the management company. Subdivision exercising internal control shall include in the annual report of the company's own assessment of management in accordance with accepted standards.

This section of the Sarbanes-Oxley Act is the most difficult to use, as most open joint stock companies managed their financial flows without the use of detailed reporting. Companies are encouraged to organize a system of internal controls over preparation of financial data periodically to expose it to the test, to determine the ways of checking their effectiveness.

\section{Results of Research}

To conduct the effectiveness of existing concepts of internal control in the conduct of an audit carried out their comparison and analysis on the proposed criteria: definition; target group; orientation; principles; goals and objectives; composition; evaluate the effectiveness (Table 1).

Table 1. Comparison of international concepts of an assessment of internal control efficiency in the conduct of an audit

\begin{tabular}{|c|c|c|c|c|}
\hline $\mathrm{SAC}$ & COBIT & $\mathrm{COSO}$ & SAS 55, SAS 78 & $\begin{array}{l}\text { Article } 404 \text { of the } \\
\text { Sarbanes - Oxley Act }\end{array}$ \\
\hline \multicolumn{5}{|c|}{ Definition of internal control system } \\
\hline $\begin{array}{l}\text { A set of processes, } \\
\text { functions, } \\
\text { activities, } \\
\text { subsystems and } \\
\text { people united } \\
\text { together or } \\
\text { deliberately } \\
\text { separated, } \\
\text { designed to ensure } \\
\text { the effective } \\
\text { achievement of } \\
\text { the goals and tasks }\end{array}$ & $\begin{array}{l}\text { Standards, } \\
\text { procedures, } \\
\text { techniques and } \\
\text { organizational } \\
\text { structures designed } \\
\text { to ensure that } \\
\text { business goals are } \\
\text { achieved, } \\
\text { undesired events will } \\
\text { be prevented or } \\
\begin{array}{ll}\text { detected and } \\
\text { corrected }\end{array}\end{array}$ & $\begin{array}{l}\text { The process is } \\
\text { carried out by the } \\
\text { Board of Directors, } \\
\text { management, } \\
\text { designed to ensure } \\
\text { the achievement of } \\
\text { the goals }\end{array}$ & $\begin{array}{l}\text { The process is } \\
\text { carried out by the } \\
\text { Board of Directors, } \\
\text { management, and } \\
\text { other personnel, } \\
\text { designed to } \\
\text { guarantee the } \\
\text { achievement of the } \\
\text { goals }\end{array}$ & $\begin{array}{l}\text { The process for } \\
\text { preparation of the } \\
\text { financial statements } \\
\text { through the use of } \\
\text { information } \\
\text { technologies, with the } \\
\text { aim of ensuring the } \\
\text { quality of financial } \\
\text { reporting and the } \\
\text { definition of rating } \\
\text { company }\end{array}$ \\
\hline \multicolumn{5}{|c|}{ Target group of the internal control system } \\
\hline Auditors (internal) & $\begin{array}{l}\text { Management, } \\
\text { auditors (information } \\
\text { system), users }\end{array}$ & Manas & (external) & $\begin{array}{lr}\text { The } & \text { senior } \\
\text { management } & \text { of the } \\
\text { Issuer, } & \text { internal } \\
\text { auditors, } & \text { the } \\
\text { independent } & \text { audit } \\
\text { company } & \end{array}$ \\
\hline \multicolumn{5}{|c|}{ The focus of the internal control system } \\
\hline $\begin{array}{l}\text { Information } \\
\text { systems }\end{array}$ & Information systems & $\begin{array}{l}\text { The organization } \\
\text { (company) in } \\
\text { general }\end{array}$ & Financial report & Financial report \\
\hline \multicolumn{5}{|c|}{ The principles of internal control system } \\
\hline $\begin{array}{l}\text { Emphasis on risk } \\
\text { assessment, } \\
\text { comparison of }\end{array}$ & $\begin{array}{l}\text { Emphasizes the role } \\
\text { and impact of IT } \\
\text { control, as it relates }\end{array}$ & Management tool & $\begin{array}{l}\text { In } \\
\text { General, } \\
\text { standards SAS 55, } \\
\text { SAS 78 focus on }\end{array}$ & $\begin{array}{l}\text { Use of the principles } \\
\text { of the internal control } \\
\text { system set out in the }\end{array}$ \\
\hline
\end{tabular}




\begin{tabular}{|c|c|c|c|c|}
\hline $\mathrm{SAC}$ & COBIT & $\mathrm{COSO}$ & SAS 55, SAS 78 & $\begin{array}{l}\text { Article } 404 \text { of the } \\
\text { Sarbanes - Oxley Act }\end{array}$ \\
\hline $\begin{array}{l}\text { costs and benefits } \\
\text { of control, } \\
\text { building control } \\
\text { devices in the } \\
\text { system, instead of } \\
\text { adding them after } \\
\text { the introduction of } \\
\text { control systems }\end{array}$ & $\begin{array}{l}\text { to } \\
\text { processes. } \\
\text { Represents } \\
\text { control structure for } \\
\text { the owner of the } \\
\text { business process }\end{array}$ & & $\begin{array}{l}\text { controls that affect } \\
\text { the reliability of } \\
\text { financial reporting } \\
\text { organization }\end{array}$ & $\begin{array}{l}\text { COSO report or } \\
\text { standard COBIT, as } \\
\text { data source on the } \\
\text { control procedures } \\
\text { and methods of } \\
\text { control in the IT } \\
\text { sector }\end{array}$ \\
\hline \multicolumn{5}{|c|}{ Goals and tasks of internal control system } \\
\hline $\begin{array}{l}\text { 1. Providing } \\
\text { information unity. } \\
2 . \quad \text { Ensuring } \\
\text { compliance with } \\
\text { the established } \\
\text { requirements. } \\
\text { 3. Ensuring } \\
\text { reliability } \\
\text { measures }\end{array}$ & $\begin{array}{l}\text { 1. The effectiveness } \\
\text { of information. } \\
2 . \\
\text { appropriateness, The } \\
\text { integrity } \\
\text { availability and } \\
\text { information. } \\
\text { 3. The reliability and } \\
\text { validity of the } \\
\text { information. } \\
\begin{array}{l}\text { 4. Confidentiality of } \\
\text { information }\end{array}\end{array}$ & $\begin{array}{l}\text { 1. The efficiency } \\
\text { and effectiveness } \\
\text { of operations. } \\
\text { 2. Compliance the } \\
\text { financial } \\
\text { statements. } \\
\text { 3. Reliability of } \\
\text { financial reporting }\end{array}$ & $\begin{array}{l}\text { 1. Reliability of } \\
\text { financial reporting. } \\
2 . \text { The efficiency } \\
\text { and expediency of } \\
\text { operations. } \\
\text { 3. Compliance with } \\
\text { applicable laws and } \\
\text { regulations }\end{array}$ & $\begin{array}{l}\text { 1. The effectiveness } \\
\text { of the process of } \\
\text { financial reporting. } \\
\text { 2. } \\
\text { appropriateness, The } \\
\text { integrity and } \\
\text { availability of } \\
\text { information. } \\
\text { 3. The functioning of } \\
\text { IT using. } \\
\text { 4. Fraud prevention }\end{array}$ \\
\hline \multicolumn{5}{|c|}{ The composition of the internal control system } \\
\hline $\begin{array}{l}\text { 1. Control } \\
\text { environment. } \\
\text { 2. Automatic and } \\
\text { manual control } \\
\text { systems. } \\
\text { 3. Control } \\
\text { procedures }\end{array}$ & $\begin{array}{l}\text { 1. Planning and } \\
\text { organization. } \\
\text { 2. The acquisition } \\
\text { and implementation. } \\
\text { 3. Delivery and } \\
\text { support. } \\
\text { 4. Monitoring }\end{array}$ & $\begin{array}{l}\text { 1. Control } \\
\text { environment. } \\
\text { 2. The risk } \\
\text { assessment. } \\
\text { 3. Actions to } \\
\text { control. } \\
\text { 4. Information and } \\
\text { communication. } \\
\text { 5. Monitoring }\end{array}$ & $\begin{array}{l}\text { 1. Control } \\
\text { environment. } \\
\text { 2. The risk } \\
\text { assessment. } \\
\text { 3. Actions to } \\
\text { control. } \\
\text { 4. Information and } \\
\text { communication. } \\
\text { 5. Monitoring }\end{array}$ & $\begin{array}{l}\text { 1. Control } \\
\text { environment. } \\
\text { 2. The risk } \\
\text { assessment. } \\
\text { 3. Actions to control. } \\
\text { 4. Information and } \\
\text { communication. } \\
\text { 5. Monitoring }\end{array}$ \\
\hline \multicolumn{5}{|c|}{ Evaluation of the effectiveness of internal control system } \\
\hline $\begin{array}{l}\text { 1. Ensuring } \\
\text { adequacy of the } \\
\text { internal control } \\
\text { system, data } \\
\text { reliability, } \\
\text { efficient use of } \\
\text { resources. } \\
\text { 2. Coordination of } \\
\text { interaction with } \\
\text { external auditors. } \\
\text { 3. Is held for a } \\
\text { certain period of } \\
\text { time }\end{array}$ & $\begin{array}{l}\text { 1. The grouping of } \\
\text { processes in } \\
\text { components, which } \\
\text { are the areas of } \\
\text { responsibility. } \\
\text { 2. Is held for a } \\
\text { certain period of time }\end{array}$ & $\begin{array}{l}\text { 1. The report cons } \\
\text { seems to be } \\
\text { responsible and } \\
\text { management. } \\
\text { 2. The internal } \\
\text { control system is } \\
\text { effective if all five } \\
\text { components are } \\
\text { functioning in } \\
\text { relation to the } \\
\text { established } \\
\text { requirements. } \\
\text { 3. Is carried out at } \\
\text { a particular time }\end{array}$ & $\begin{array}{l}\text { 1. The internal } \\
\text { control system is } \\
\text { effective if all } 5 \\
\text { components are } \\
\text { functioning in } \\
\text { relation to the } \\
\text { established } \\
\text { requirements. } \\
\text { 2. The external } \\
\text { auditors report on } \\
\text { the shortcomings of } \\
\text { the system of } \\
\text { internal control that } \\
\text { influence reporting. } \\
\text { 3. Is held for a } \\
\text { certain period of } \\
\text { time }\end{array}$ & $\begin{array}{l}\text { 1. The assessment } \\
\text { should include } \\
\text { disclosure about the } \\
\text { shortcomings of the } \\
\text { internal control } \\
\text { system. } \\
\text { 2. The guidance } \\
\text { should not give a } \\
\text { positive assessment } \\
\text { of the internal control } \\
\text { system in the } \\
\text { presence of one or } \\
\text { more of the } \\
\text { shortcomings in the } \\
\text { functioning. } \\
\text { 3. Is held for a certain } \\
\text { period of time }\end{array}$ \\
\hline
\end{tabular}

Almost all the concepts define the internal control system as the process towards the achievement of any goals (reducing risks, financial reporting and other) (Pugachev, 2010). The concept of SAC is the control system as a collection of processes, functions, activities, subsystems and people United together or deliberately separated, but also aimed at the achievement of goals and objectives. And only the standard COBIT sees the internal control system is not in the process, and specifically in the rules, procedures, practices and organizational structures.

Each concept has its target group, the representatives of which can be as auditors (internal and external) and 
management organization and the company's employees, ordinary users. Belonging to the target group must also be taken into account when forming its own system of internal control (Feng et al., 2009).

Two of the presented concepts and auditing standards SAS 55 and 78, article 404 of the Sarbanes - Oxley Act-focus system of internal control on financial reporting. SAC and the COBIT standard - control-information systems, the concept of COSO more universal in the choice of orientation, he focuses on the control of the organization as a whole.

All of these concepts, as a rule, the emphasis on controls, differentiating only their impact on the operation and evaluation monitoring system. Priority seen the principles set forth in COSO, where controls are built into operating activities, and not built on its base.

Since the focus of different concepts, different and the goals and objectives of the internal control systems. You can mark only one goal, which appears as a rule, almost all the submitted documents, is ensuring the efficiency of the process or transaction.

The complete list of the internal control system is presented in the audit standards SAS 55 and 78, article 404 of the Sarbanes-Oxley Act and the concept of COSO. It consists of five components-control environment, risk assessment, information system, control activities and monitoring.

In the criteria for evaluating the effectiveness of internal control presents the greatest range of requirements to assessment of the effectiveness of the control system. It is necessary to note the basic requirements for the assessment (Jokipii, 2010):

the functioning of all five components of the control system (control environment, risk assessment, information system, control activities and monitoring);

the reporting of defects to the responsible person, management, auditors;

the use of automated and manual operation of the internal control system;

assessing the effectiveness of tools and controls.

Thus, review of the concepts of internal control contains a lot in common. Each of documents flows from the previous one. However, there are differences. Documents have different target audience that is accessed, the purpose of the document, the depth of control. The document COBIT useful for a wide range of users, but the main ones are the following target groups: management, internal users and auditors. SAC is focused mostly on internal auditors; COSO-on managers and the Board of Directors; and SAS 55 and 78 of the external auditors.

The document COBIT describes in detail the controls designed to support business goals. SAC focuses on data, COSO provides a more extensive control options for the company and SAS 55 and 78 more to consider in detail the audit of the financial statements. SAC and COSO-two full document describing the internal control. SAS 55 and 78 included in the list of standards. Four documents complement each other. SAC, COSO and SAS 55 and 78 especially useful for users such as: internal and external auditors, lawyers, managers and company executives.

The analysis of the requirements stated in normative documents, allowed to summarize the world experience of work in this direction and form the most important criteria for the development of internal control. It should be noted that, analyzing and describing the proposed criteria in developing its internal control system, it is necessary to consider that the choice of the concept of complex concepts outlined in normative documents depends on the activities of the enterprise, from the policy of management of the enterprise and the possibility of use in certain circumstances.

\section{References}

American Institute of Certified Public Accountants. Statement on Auditing Standards No. 53, The Auditor's Responsibility to Detect and Report Errors and Irregularities, New York, NY, AICPA, 1988.

American Institute of Certified Public Accountants. Statement on Auditing Standards No. 78, Consideration of Internal Control in a Financial Statement Audit: An Amendment to SAS No. 55, New York, NY, AICPA, 1996.

Armour, M. (2000). Internal Control: Governance Framework and Business Risk Assessment at Reed Elsevier, Auditing. A Journal of Practice \& Theory, 19. http://dx.doi.org/10.2308/aud.2000.19.s-1.75

Burtsev, V. V. (2000). Organizatsiya sistemyi vnutrennego kontrolya kommercheskoy organizatsii. M., 386 s.

Chenhall, R. H. (2003). Management control systems design within its organizational context: Findings from contingency-based research and directions for the future. Accounting Organizations and Society, 28, 
127-168. http://dx.doi.org/10.1016/S0361-3682(01)00027-7

Colbert, J. L., \& Bowen, P. L. (1996). A Comparison of Internal Controls: CobiT, SAC, COSO and SAS 55/78. IS. Audit and Control Journal, 4, 26-35.

Committee of Sponsoring Organizations of the Treadway Committee (COSO). (1992). Internal Control-Integrated Framework, Executive Summary. Retrieved from http://www.coso.org

Feng, M., Li, C., \& McVay, S. (2009). Internal control and management guidance. Journal of Accounting and Economics, 48, 190-209. http://dx.doi.org/10.1016/j.jacceco.2009.09.004

International Standards for the Professional Practice of Internal Auditing (Standards). (2012). The Institute of Internal Auditors. IT Governance institute. Cobit. Control objectives. Management guidelines. Maturity models. Retrieved from http://www.isaca.org

Jokipii, A. (2010). Determinants and consequences of internal control in firms: A contingency theory based analysis. J. Manag Gov., 14, 115-144. http://dx.doi.org/10.1007/s10997-009-9085-x

Mair, W. C. (2002). System Assurance and Control. The Institute of Internal Auditors Research Foundation.

Pugachev, V. V. (2010). Vnutrenniy audit i kontrol. Organizatsiya vnutrennego audita $v$ usloviyah ekonomicheskogo krizisa. M., $224 \mathrm{~s}$.

Sarbanes-Oxley Act of 2002. Retrieved from https://www.sec.gov/about/laws/soa2002.pdf

\section{Copyrights}

Copyright for this article is retained by the author(s), with first publication rights granted to the journal.

This is an open-access article distributed under the terms and conditions of the Creative Commons Attribution license (http://creativecommons.org/licenses/by/3.0/). 